\title{
Massive Left Atrial Myxoma Presenting With Troponin-Positive Chest Pain
}

\author{
Aileen Kearney · Niall Corry · Ian B. A. Menown
}

Received: June 5, 2020 / Published online: July 27, 2020

(C) The Author(s) 2020

\section{ABSTRACT}

Atrial myxomas are the most prevalent primary cardiac tumors. The clinical presentation is variable and often poses a diagnostic challenge. Here we describe the case of a 52-year-old woman who presented with troponin-positive chest pain, exertional dizziness, and dyspnea as a consequence of a massive left atrial myxoma, which was successfully treated with surgical resection.

Keywords: Atrial myxoma; Cardiac tumor; Echocardiography; Systemic embolization

Digital features To view digital features for this article, go to https://doi.org/10.6084/m9.figshare.12535400.

Electronic Supplementary Material The online version of this article (https://doi.org/10.1007/s40119020-00187-2) contains supplementary material, which is available to authorized users.

A. Kearney $(\varangle)$. I. B. A. Menown

Department of Cardiology, Craigavon Cardiac

Centre, Southern Trust, Craigavon, UK

e-mail: akearney13@qub.ac.uk

N. Corry

Department of Pathology, Royal Victoria Hospital, Belfast, UK

\section{Key Summary Points}

Myxomas are the most common benign primary cardiac tumors.

Clinical presentation can vary from an incidental finding to symptoms caused by cardiac obstruction, embolization, and constitutional upset.

We observed a case of troponin-positive chest pain in a patient with a large left atrial myxoma due to coronary artery embolization, a rare but recognized complication.

Urgent surgical resection is indicated to prevent embolic complications and sudden death.

\section{INTRODUCTION}

Primary cardiac tumors are rare, with an estimated prevalence of 1 in 2000 [1]. Approximately $10 \%$ of primary cardiac tumors are malignant and $90 \%$ are benign. Myxomas represent the most common type of benign cardiac tumor and occur in the left atrium in $75-85 \%$ of cases. Clinical presentation can vary considerably and may include non-specific 
constitutional symptoms related to interleukin 6 , thromboembolic events, or symptoms related to the obstructive effects of the tumor at the mitral valve orifice.

\section{CASE PRESENTATION}

A 52-year-old woman with a past medical history of treated primary hyperthyroidism presented to the emergency department (ED) with episodes of dizziness and dyspnea on exertion, fatigue, arthralgia, and myalgia for several months. Cardiovascular risk factors included a family history of coronary artery disease and current smoking status. Clinical observations and electrocardiogram on arrival to ED were within normal limits. Initial high-sensitivity troponin $\mathrm{T}$ (hsTnT) was $4 \mathrm{ng} / \mathrm{l}$ (normal range $<14 \mathrm{ng} / \mathrm{l})$. Inflammatory markers including C-reactive protein (CRP) and erythrocyte sedimentation rate (ESR) were within normal limits. While in the department, she developed central chest heaviness with dynamic anterolateral T-wave inversion on electrocardiogram. Repeat hsTnT, $3 \mathrm{~h}$ after presentation, was elevated at $83 \mathrm{ng} / \mathrm{l}$. She was treated as a suspected acute coronary syndrome and admitted to the coronary care unit for further management.

Transthoracic echocardiogram demonstrated a large left atrial mass measuring $7.1 \mathrm{~cm} \times 4.6 \mathrm{~cm}$ attached to the interatrial

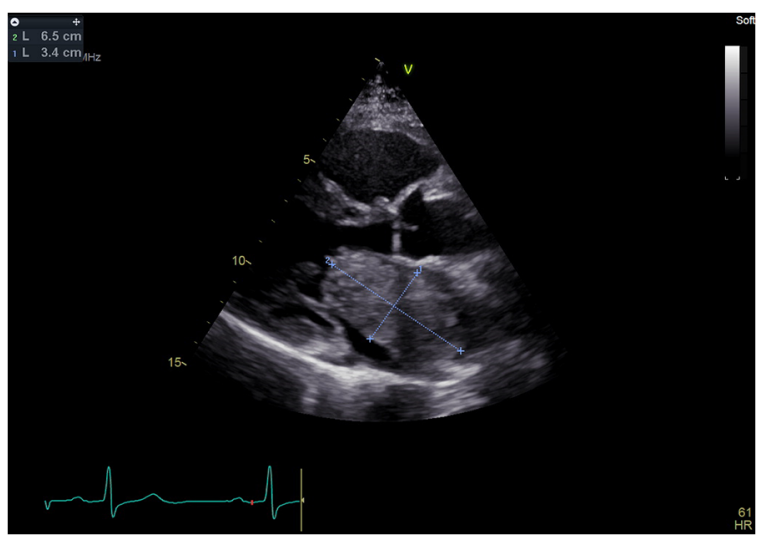

Fig. 1 Transthoracic echocardiogram demonstrating the parasternal long-axis view of the left atrial myxoma prolapsing through the mitral valve in diastole

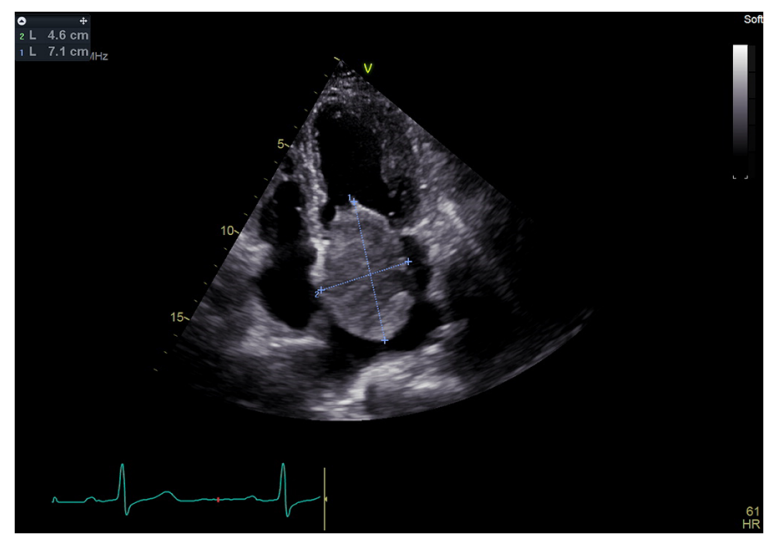

Fig. 2 Apical four-chamber view of left atrial myxoma prolapsing into the left ventricle

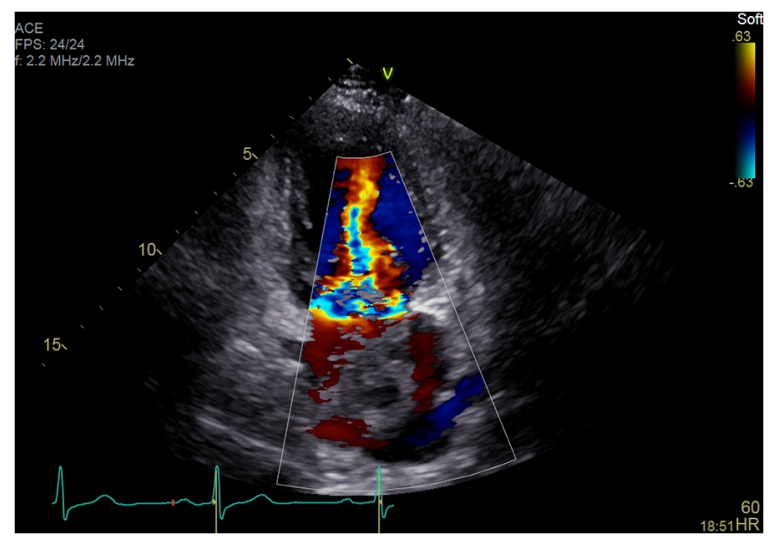

Fig. 3 Apical two-chamber view with color flow Doppler demonstrating turbulent flow at the mitral valve orifice in diastole

septum and protruding through the mitral valve into the left ventricle in diastole (Figs. 1, 2,3 and videos $1-3$ ). The mean gradient across the mitral valve at rest was $6 \mathrm{mmHg}$ in keeping with hemodynamic effects similar to that of moderate mitral stenosis. Left and right ventricular size and function were within normal limits. Cardiac catheterization demonstrated angiographically normal coronary arteries but did show vascular supply to the mass (at 7 o'clock) and vascular movement in keeping with movement of the mass (video 4).

She underwent urgent cardiac surgery to excise the left atrial mass. The stalk of the mass was identified and excised circumferentially from the interatrial septum. Left atriotomy was 

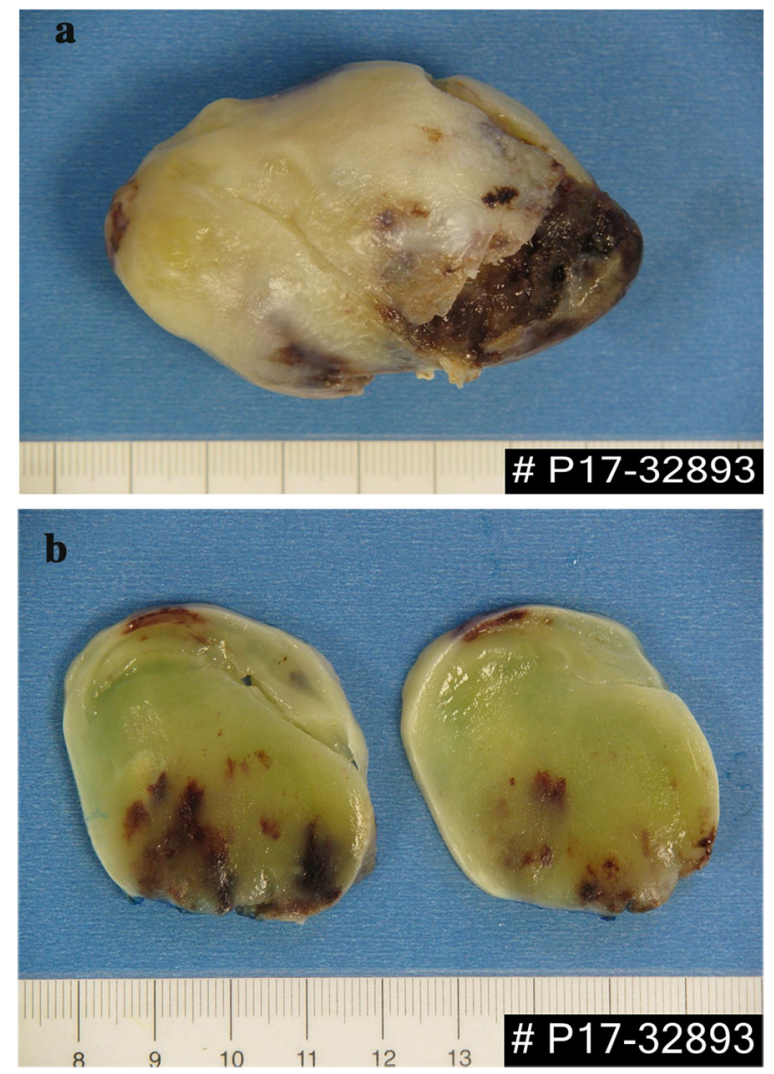

Fig. 4 a, b Gross pathological appearance of left atrial myxoma

performed to deliver the stalk (measuring $22 \mathrm{~mm} \times 2 \mathrm{~mm} \times 3 \mathrm{~mm}$ ) and the left atrial mass (measured $67 \mathrm{~mm} \times 48 \mathrm{~mm} \times 30 \mathrm{~mm}$ and weighing 62 g) (Fig. 4). Histology demonstrated hypocellular myxoid stroma consistent with an atrial myxoma (Fig. 5). Her post-operative recovery was uncomplicated, and she was discharged 5 days after surgery. We thank the patient for providing their consent to publish this case report.

\section{DISCUSSION}

Primary cardiac tumors are rare, with an incidence rate of 1.38 per 100,000 people per year in a population study [1]. Of these, myxomas represent the majority and occur in the left atrium in $75-85 \%$ of cases. Myxomas are typically benign tumors and clinical presentation can vary from an asymptomatic incidental
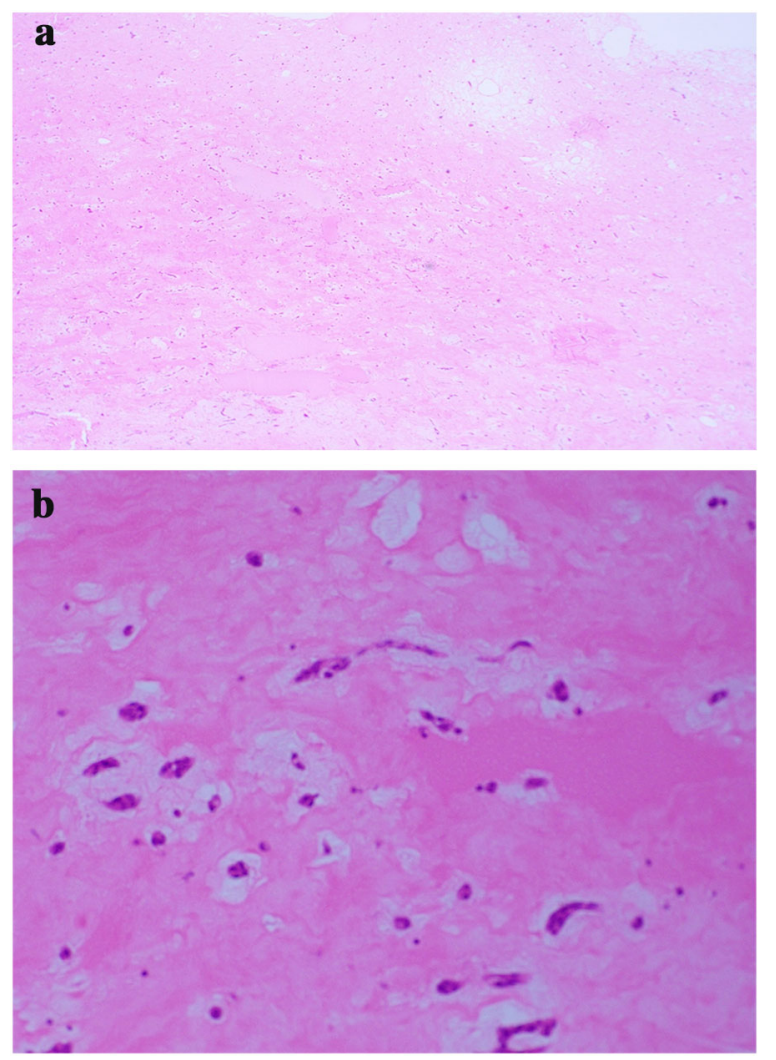

Fig. 5 a Histological examination showing loose hypocellular myxoid stroma (hematoxylin and eosin $\times 20$ ). b Higher-power view of myxoid stroma $(\times 40)$

finding to symptoms caused by cardiac obstruction (cavity, valve, or outflow tracts), embolization and constitutional upset [2]. A possible explanation for our patient's presentation with troponin-positive chest pain and associated ECG changes is coronary artery embolism, a recognized and potentially fatal complication of atrial myxoma, leading to transient coronary occlusion and myocardial infarction. The incidence of coronary artery embolization has been reported as 0.06\% [3], which is likely an underestimate, as spontaneous recanalization has been reported in 23\% of such cases [4] and may occur even more frequently. Urgent surgical resection was indicated in this case both due to the large size leading to intermittent obstruction and the suspected coronary embolic event. 


\section{ACKNOWLEDGEMENTS}

We thank the participants of this study.

Funding. No Rapid Service Fee was received by the journal for the publication of this article.

Authorship. All named authors meet the International Committee of Medical Journal Editors (ICMJE) criteria for authorship for this article, take responsibility for the integrity of the work as a whole, and have given their approval for this version to be published.

Disclosures. The authors Aileen Kearney and Niall Corry have nothing to disclose. Ian B. A. Menown is the Editor in Chief for Cardiology and Therapy but otherwise has nothing to disclose.

Compliance with Ethics Guidelines. We thank the patient for providing their consent to publish this case report.

Data Availability. Data sharing is not applicable to this article, as no datasets were generated or analyzed during the current study.

Open Access. This article is licensed under a Creative Commons Attribution-NonCommercial 4.0 International License, which permits any non-commercial use, sharing, adaptation, distribution and reproduction in any medium or format, as long as you give appropriate credit to the original author(s) and the source, provide a link to the Creative Commons licence, and indicate if changes were made. The images or other third party material in this article are included in the article's Creative Commons licence, unless indicated otherwise in a credit line to the material. If material is not included in the article's Creative Commons licence and your intended use is not permitted by statutory regulation or exceeds the permitted use, you will need to obtain permission directly from the copyright holder. To view a copy of this licence, visit http://creativecommons.org/licenses/by$\mathrm{nc} / 4.0 /$.

\section{REFERENCES}

1. Cresti A, Chiavarelli M, Glauber $M$, et al. Incidence rate of primary cardiac tumors: a 14-year population study. J Cardiovasc Med (Hagerstown). 2016;17(1): $37-433$.

2. Karabinis A, Samanidis G, Khoury M, Stavridis G, Perreas K. Clinical presentation and treatment of cardiac myxoma in 153 patients. Medicine (Baltimore). 2018;97(37):e12397.

3. Lehrman KL, Prozan GB, Ullyot D. Atrial myxoma presenting as acute myocardial infarction. Am Heart J. $1985 ; 110(6): 1293-5$.

4. Panosa A, Kalangosb A, Sztajzela J. Left atrial myxoma presenting with myocardial infarction: Case report and review of the literature. Int J Cardiol. 1997;62: $73-5$. 